\title{
Selected determinants of multi-family housing in Katowice in the 2030 perspective
}

\author{
Beata Komar \\ https://orcid.org/0000-0002-8276-704X \\ beata.komar@polsl.pl \\ Faculty of Architecture, Silesian University of Technology
}

\begin{abstract}
The article deals with the subject of selected conditions of multi-family housing in Katowice, which the author includes: city documents indicating the prospective directions of the city's development, demographic analyzes and other factors such as: the image of the city in general public opinion and the state of the air. The aim of the article is to take a general look at the indicated factors in Katowice and to use them to determine the approximate housing forecast for the city. The research methodology is based on literature analyzes and the author's long-term observations.
\end{abstract}

Key words: multi-family housing, city documents, demographic, smart city

\section{Introduction}

The basis for housing construction, especially multi-family housing - because it is most dependent on various types of criteria, are (or should be) conditions: strategic, demographic and other specific for a given region.

The strategic determinants of the author include mainly city documents, which indicate the prospective directions of development of the city and the region in terms of housing.

Demographic determinants appear in the study of the development of a given city, Central Statistical Office (Polish: GUS) statistics and research conducted by various research centers. For Katowice, the most significant are the long-term analyzes carried out by prof. Jerzy Runge with a team from the Department of Economic Geography of the University of Silesia.

Other factors that may influence the housing issue in a given city are e.g. labor market (economic factors), urban attractiveness, legal considerations (e.g. land ownership), air condition and many others. The aim of the article is to take a general look at the indicated factors in Katowice and to use them to determine the approximate housing forecast for the city.

\section{Strategic conditions - main city documents}

The most important strategic conditions for the city of Katowice are the City Development Strategy "Katowice $2030 "$ and Katowice. Study of the conditions and directions of spatial development. 


\section{The City Development Strategy "Katowice 2030"}

The City Development Strategy Katowice 2030 was adopted by the Katowice City Council by Resolution No. XIX / 365/15 on December 17, 2015 and is currently the most promising document for city planning and plays a superior role for other city documents. At the same time, the earlier document, ie the resolution, became invalid from 2005 on the same issue ${ }^{1}$. The provisions of the strategy are also in line with the goals of the 2023 National Urban Policy ${ }^{2}$. In the current Strategy, several most important points of gravity can be mentioned, which are defined in the form of interconnected strategic fields, they are the following elements: quality of life, metropolitan and inner-city areas, entrepreneurship and economic development, transport and urban logistics.

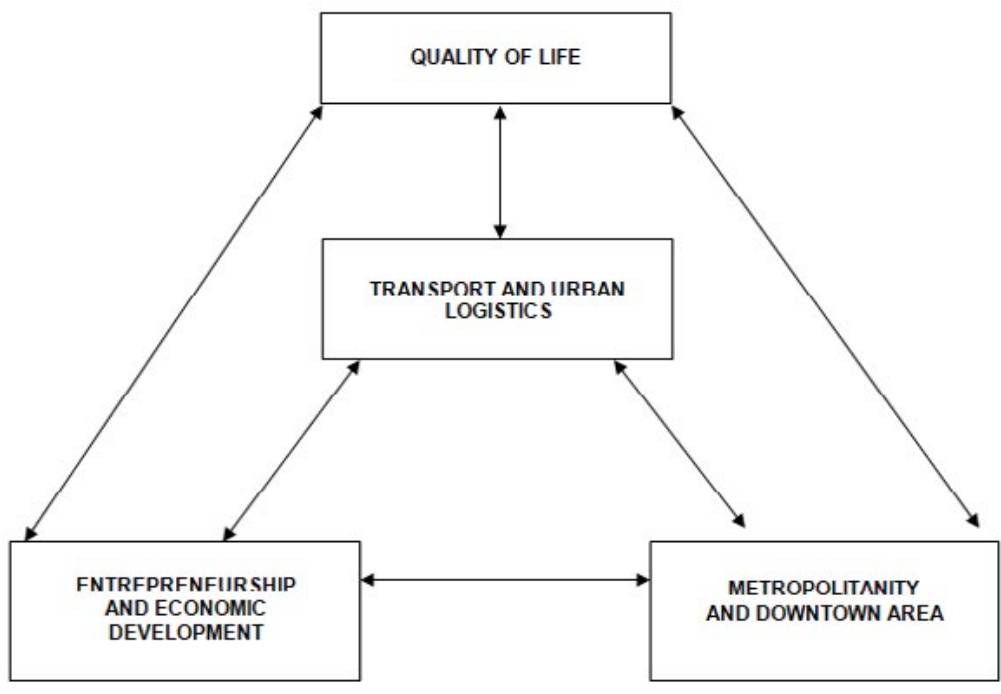

Fig. 1. Center of gravity in the development of the city of Katowice

Source: Own study based on the City Development Strategy „Katowice 2030”

Table 1. Strategic fields and their structure

\section{Strategic fields}

Quality of life

Metropolitanity
and city area
Entrepreneurship and economic development

Transport and urban logistics
Housing

Activities, events and metropolitan products

New economy, environments and innovative networks

\section{Components of strategic fields}

Public services

Social and natural living environment

Agglomeration accessibility of the downtown area

$$
\begin{gathered}
\text { Metropolitan } \\
\text { infrastructure } \\
\text { and cooperation } \\
\text { networks }
\end{gathered}
$$

Business support institutions

$$
\begin{aligned}
& \text { Metropolitan } \\
& \text { public and } \\
& \text { business spaces } \\
& \text { and residential }
\end{aligned}
$$

\section{Activity of young} people in creating a new economy

\section{Local} entrepreneurship and crafts
Transport networks ensuring connectivity at various scales and spatial ranges
Infrastructure of multifunctional transport systems and city logistics
Intelligent management of transport and logistics systems

Source: City Development Strategy "Katowice 2030"

1 Resolution No. LII / 1068/05 of the Katowice City Council of December 19, 2005. on the development strategy of the city of Katowice.

2 City Development Strategy „Katowice 2030” https://bip.katowice.eu/Lists/Dokumenty/Attachments/95384/1450771333.pdf, page 3, accessed: 19/11/2020. 
Housing, i.e. the issue discussed in this article, is part of the strategic field of the quality of life. As we read further in the document under discussion, the strategic principle of the development policy of the city of Katowice in relation to the quality of life should focus on the specialization of the functions of urban districts and the decentralization of the service system for residents ${ }^{3}$, where the priority is to increase the attractiveness of the living environment. This will allow Katowice to transform into a city with a balanced functional and spatial structure in relation to the city center area and districts ${ }^{4}$.

High-quality housing standards in districts and reduced spatial spans in living conditions should be implemented through the development and modernization of housing construction and energy reconstruction of the city ${ }^{5}$. It is also worth adding that the general vision of the city's development is based on the so-called $\mathbf{4} \mathbf{i}$, that is: intelligence, innovation, integration and internationalization. Supporting intelligent development will create, among others intelligent systems of housing construction, service provision (including public) and environmental management ${ }^{6}$.

In detail, the vision of the quality of life should focus on:

- providing attractive and high-tech housing for current and new residents,

- guaranteeing freedom of choice to all residents and access to the sphere of services increasing their diversity, improving living conditions in a manner corresponding to modern civilization standards,

- fostering civic activity ensuring public safety and ecological and improving the environmental and technical quality of public spaces ${ }^{7}$.

As can be inferred from this document, quality of life is not focused in it only in providing housing, but also at their technological level, it also applies to high-quality public services and spaces, public safety and environmental protection.

\section{Katowice. Study of the conditions and directions of spatial development}

The study of the conditions and directions of spatial development for the city of Katowice was adopted by the Resolution of the City Council No. XXI / 483/12 of April 25, 2012. According to the Study, the areas of multi-family housing cover 875.04 ha, which is $5.31 \%$ of the city's area, and are occupied by the following districts - northern: Śródmieście and large estates: Tysiąclecia, Witosa and Paderewskiego. They also clearly stand out in Szopienice - Burowiec, Ligota - Panewniki, Piotrowice - Ochojec (housing estate Odrodzenia) and Brynów - Załęska Hałda.

In 2005-2007, 57\% of all flats put into use in Katowice were multifamily housing. At the same time, both in the city and the entire metropolis there was a slower increase in new flats than in Warsaw and other regional centers, which can be explained by the high number of flats per 1000 inhabitants.

In the long-term perspective (15 years), the Study recommends the following steps aimed at diversifying the structure of the housing offer:

- increasing the offer of new apartments focused on the needs of young people,

maintaining relatively lower housing prices,

- supporting the development of housing estates characterized by the highest quality of urban and architectural solutions ${ }^{8}$.

In turn, the following are considered negative trends in the development of the housing structure in the document:

a compacting the buildings of the existing multi-family housing estates, thus reducing their resources of green areas, 
- introducing housing investments in the valleys,

- excessive intensification of buildings, leading to inefficiency of communication systems

- location of investments in areas endangered with noise, e.g. next to busy traffic routes ${ }^{9}$.

On the basis of the conducted analysis, it can be concluded that in terms of quality of life, and in particular housing in the broad sense, both documents are consistent.

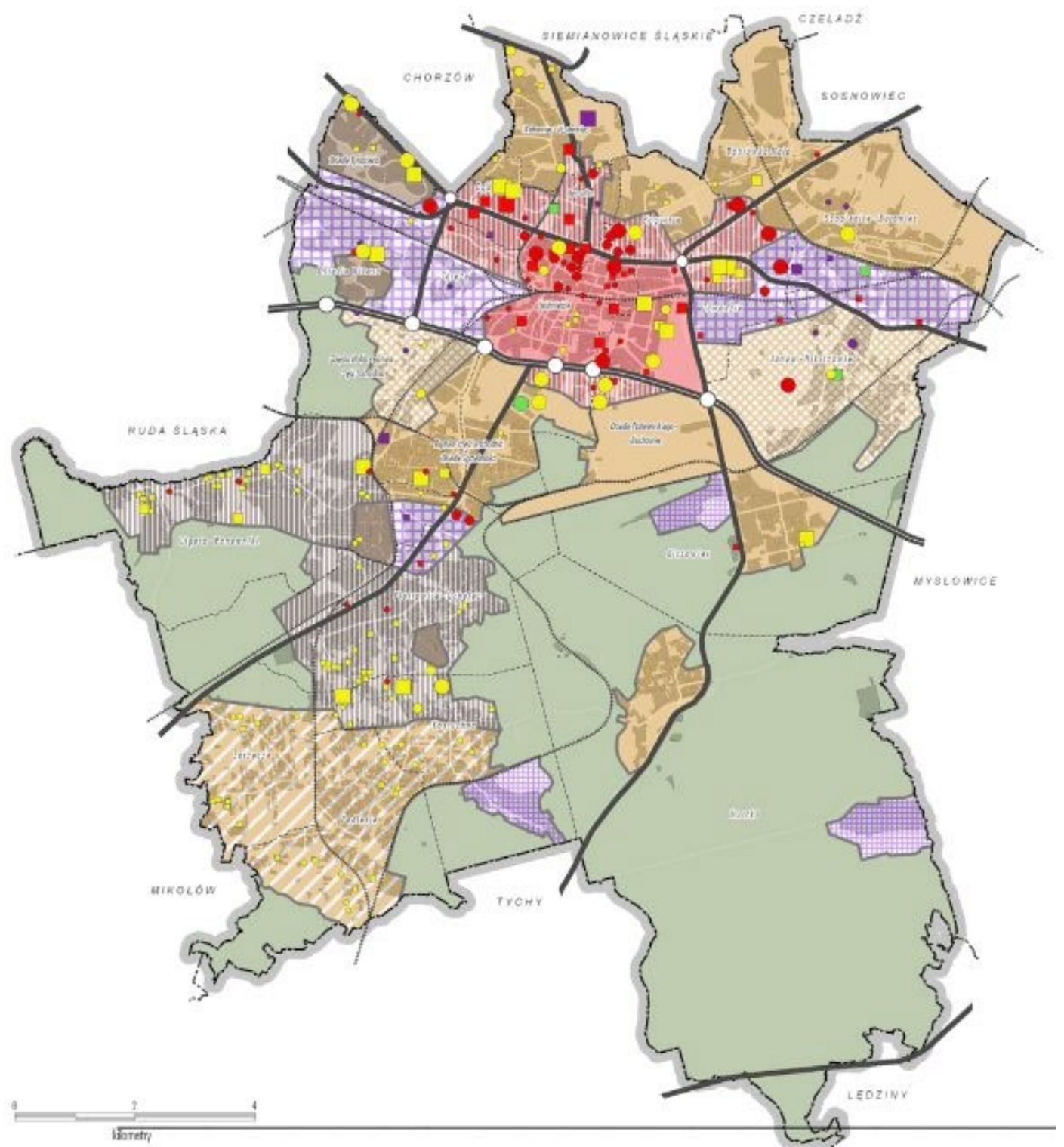

Fig. 2. Main elements of the city structure, markings:

areas of shaped multi-family housing estates,

$\square$ significant residential and service investments in progress (investment rank determined by the square size)

$\bigcirc$ potential housing and service investments (investment rank determined by the size of the circle)

Source: Katowice. Study of the conditions and directions of spatial development 


\section{Demographic conditions}

In the $20^{\text {th }}$ century, Katowice was the city with the largest population growth within the agglomeration ${ }^{10}$. In 1991, the historic maximum population was reached in the Śląskie Voivodeship. Unfortunately, since 1992 a decrease in the number of people has been observed, and now Katowice has lost 80 thousand people ${ }^{11}$. In 1988, the capital of Upper Silesia had 367,000 inhabitants, in 2009 - 309 thousand, and by 2030 their number is to drop to 229 thousand. - This is a very high demographic decline - emphasizes prof. Jerzy Runge, quoted by Marlena Nykiel. He adds that Katowice is losing because it still offers little. On the local labor market, new jobs are still being created at a too slow pace, and without that, young Katowice residents will not be encouraged to stay in the city, not to mention attracting residents from outside the voivodeship ${ }^{12}$.

According to the Study, a very strong factor influencing the city's population level is the attractiveness of the living environment, the generally low assessment of the quality of Katowice's space may be a significant factor in the decision to leave the city by residents ${ }^{13}$. As it seems, the demographic forecasts for the city are not very favorable.

\section{Other factors determining multi-family housing}

Among other factors influencing the development of housing in Katowice there are, for example, air quality. In Katowice, large industrial plants have been shutting down for many years, but the improvement of air quality is a long-term process, also associated with soil reclamation, increasing awareness of residents and the use of ecological heat sources also in households.

Unfavorable values of this factor are not conducive to the increase in the city's population. As Marlena Nykiel writes ${ }^{14}$, this factor also has an impact on the emergence of developer apartments in Katowice. However, this does not mean a stagnation on the primary housing market. In 2015, developers launched nearly 20 new phases of projects within the city limits, in which an unprecedented number of over 1.3 thousand was introduced for sale. premises. This is over 126\% more than in 2014.

Flats that could be purchased with credit predominated with an additional payment in the "Flat for young people" program. The president of REAS - a consulting company that tracks development investments - Kazimierz Kirejczyk believes that the basic barrier to the development of the primary market in Katowice is the unfavorable relationship between the costs of building a new building and the prices of premises on the secondary market.

The long-term research carried out by the author in the Tysiąclecie estate has also shown another phenomenon, namely the exodus of people from older blocks to new housing estate investments. This was indicated by both the developer Activ Investment and J.W. Construction Holding S.A., responsible for the construction of new residential buildings on the estate ${ }^{15}$.

Another factor that has a positive impact on the development of housing in Katowice is the creation of the Metropolis $\mathrm{GZM}^{16}$, as pointed out by prof. Runge already in $2016^{17}$, mainly due to the development of transport, communication and services and their concentration in one entity. The promotion of the region may also be important, aimed at breaking public opinion with stereotypes such as: contaminated natural environment, low quality of life, and outdated economy.

10 Ibidem, p. 44.

$11 \mathrm{~J}$. Runge, Tendencies of depopulation and demographic aging in the Silesian Voivodeship and the model of the new re-urbanization of the region [in]: Gasidło K., Klasik A., Muster R., New urbanization on the old substrate, Publishing House of the University of Economics, Katowice 2019, p. 102-112.

12 M. Nykiel, Developers do not want to build in Katowice. Why ?, Gazeta Wyborcza, 27/07/2016

13 Katowice. Study... p. 53

14 M. Nykiel, ibidem.

15 Focus interview with a developer at Activ Investment on November 10, 2011. and B. Komar, Interview with developer J.W. Construction Holding S.A, on November 18, 2020

16 Regulation of the Council of Ministers of June 26, 2017 on the establishment of a metropolitan union in the Silesian Voivodeship under the name Metropolis GZM (Journal of Laws of 2017, item 1290).

17 M. Nykiel, ibidem. 
Katowice, ul Kossutha 6 AQI: Katowice, ul Kossutha 6 Rei
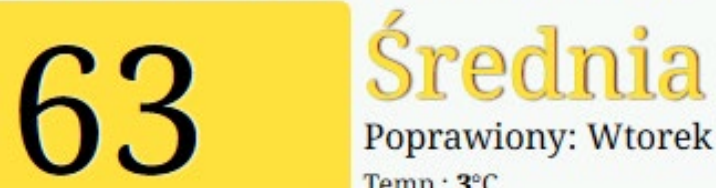

Poprawiony: Wtorek 16:00

Temp.: $3^{\circ} \mathrm{C}$

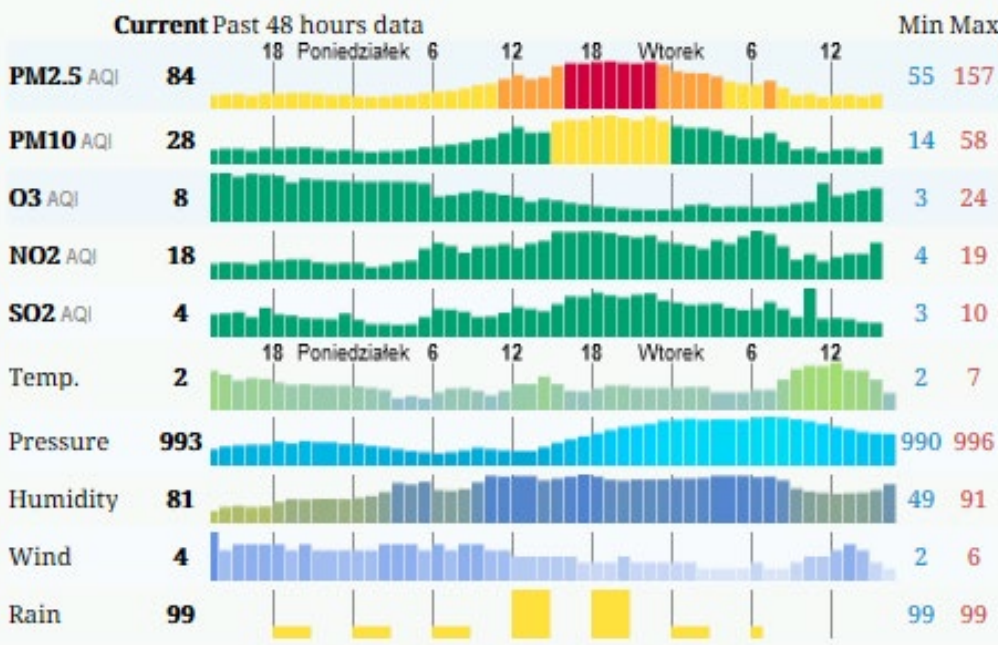

Fig. 3. Katowice. Air quality index values, data as of November 24 2020, red color means unhealthy air

Source: Air pollution in Katowice: https://aqicn.org/map/katowice/ $\mathrm{pl} /$

Fortunately, the Report on Metropolises for the city of Katowice prepared by PwC, showing the state of affairs for $2015^{18}$, indicates that the city's situation is not as bad as one might suppose. The report addresses the following issues: people, quality of life, image, institutions, infrastructure, finances, investments. The conclusion of the report is as follows - strengths of the city: excellent location, well-developed infrastructure and labor market, a large number of graduates of technical and science faculties, healthy finances; weaknesses: unfavorable image of the city, difficult demographic situation, low level of obtained European funds per capita.

According to the author, the image of the city has improved significantly, mainly due to the functioning of the Culture Zone (2015) and the creation of a new city market (2016), i.e. places that are the actual showcase of the city. At the time of writing, these investments were still waiting for implementation.

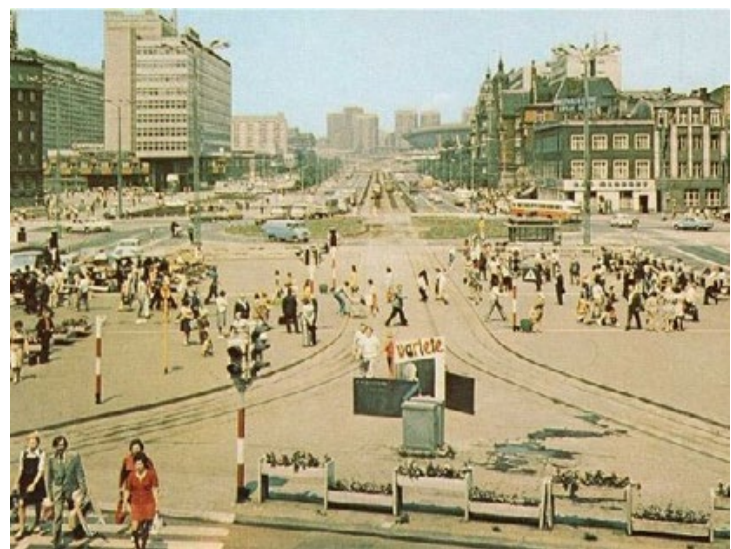

Fig. 4. Katowice. Market, view from the 1970s Source: Internet

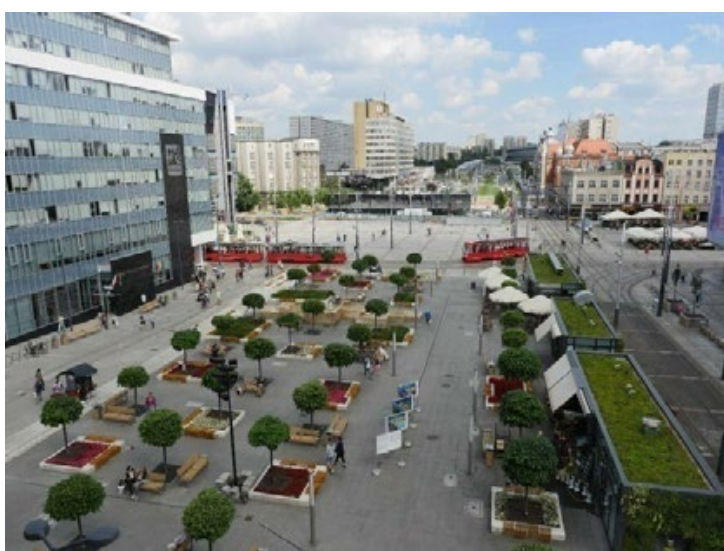

Fig. 5. Katowice. Market, a contemporary view Source: katowice24.info 


\section{Examples of investments in the field of multi-family housing in Katowice}

Developers and still housing cooperatives are responsible for the contemporary shaping of the multi-family housing market in Katowice.

\section{Cooperative enterprises}

The main housing cooperatives in the city are Katowice Housing Cooperative (Polish: KSM), SM Piast and SM Paderewski. KSM (operating since 1957) has 17 housing estates in its resources and these investments were systematically implemented by several houses - not focusing on entire estates - in different districts of the city, thus ensuring an even development of the entire urban fabric. At the same time, along with the development of the housing estates, the communication network of the city and the region was built. The estates built at that time were shaped on the basis of the regulations forcing the creation of housing estate infrastructure and urban standards defining the size of a residential unit ${ }^{19}$.

Currently, KSM is not only focused on the exploitation of its resources, but also tries to expand them or even build new housing estates. Such undertakings include the following:

- Świerkowe Estate, Katowice-Panewniki,

- Zielony Zakątek Housing Estate, Katowice, Daszyńskiego St.

- 8 buildings in the Zawodzie housing estate, Bohaterów Monte Cassino St.

- Murcki Estate, Domeyki St., 1 building with 20 apartments - Recreational Valley - Small Pond, Recreational Valley - Big Pond, Graniczna Estate - Graniczna-Puławskiego St.

- in prospective plans:

the Ligota housing estate, Ligocka St.- 1 building

- the Szopienice estate, Moravia St. - Osiedlowa St. - 4 buildings with 50 apartments, Morawa St. (Sosnowiecka St.) - Residential complex for seniors with care and medical facilities -1 building with 60 apartments ${ }^{20}$.

The space of its estate was decided differently by SM Piast (operating since 1983), which sold some of its undeveloped land to the developer Activ Investment, and within the borders of Tysiąclecia Estate, an investment called Parkowa Strona Miasta ( 2 buildings) and the Cztery Wieże housing estate (4 buildings) were created. The Nowe Tysiąclecie investment is also currently being completed (5 objects), developer J.W. Construction Holding S.A. There is a clear difference between the investing KSM and the operating SM Piast, which results primarily from the scope of activities (SM Piast 1 estate, KSM 17 housing estates) and related financial possibilities. In general, it can be said, based on many years of observations carried out by the author, that the situation of housing cooperatives on the Polish housing market is not easy, there is a lack of economic solutions, positive legal solutions, and friendly lending that would allow for larger construction projects.

\section{Katowice development market - selected examples}

There are currently over a dozen development companies operating on the Katowice development market, to mention only the following: Activ Investment Sp. z o.o. (housing estates: Parkowa Strona Miasta, Cztery Wieże), Murapol S.A. (housing estate: Mała Skandynawia), Geo Grupa Deweloperska (housing estate: Atrium Geo), ATAL S.A. (housing estates: Ligota Park, Apartamenty Grunfeld), MK Inwestycje (housing estate: Zagajnik and apartment building Widok), J.W. Construction Holding S.A. (housing estate: Nowe Tysiąclecie), TDJ Estate (housing estate: Franciszkańskie).

19 B. Komar, The contemporary quality of the cooperative housing estate in the light of the principles of sustainable development on selected examples, Publishing House of the Silesian University of Technology, Gliwice, 2014.

20 KSM, Directions for the development of economic, social and cultural activities of the Katowice Housing Cooperative for 2020. 


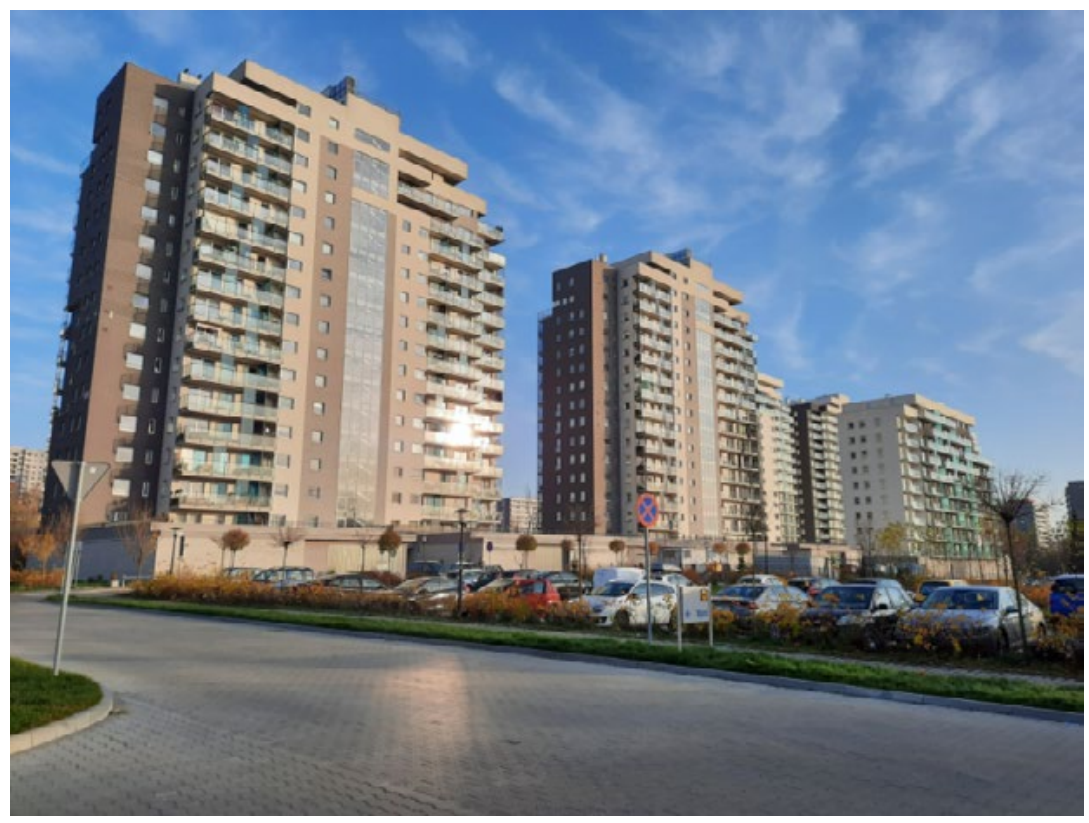

Fig. 6. Nowe Tysiąclecie Estate Source: Photo taken by the author

Projects for this type of construction have a properly calculated price, which increases with the increase in the investment standard, and thus the price of the apartment increases. Taking this into account, the developer must skillfully navigate in a given price group so as not to exceed his own funds and those entrusted by clients or banks. It is also associated with the use of such building materials that correspond to a given price group. Acquisition of land for real estate by a developer may take place through tenders or through direct purchase of land from their owners. In Katowice, which is also confirmed by the research of Professor J. Runge ${ }^{21}$, the southern areas are considered the most attractive. The size of a housing estate is related to the developer's financial resources.

In the times of the Polish People's Republic, when large housing estates were built, these matters were approached in a different way, but the result was similar. The projects of the estates included schools, broadly understood services, infrastructure, but as a result of the unrelenting hunger for housing, mainly apartment blocks were built, and only after a few years the estates were equipped with services and efficient communication. The concept of a shopping center was not yet known, so smaller services were built in the estates. Today, it is enough to build one shopping center outside of residential areas to provide access to services for several estates. The estates that are currently under construction are mainly closed ones, focused on living and recreation not trade, which could cause people not living on the estate to appear on the estates, which could have a negative impact on the sense of security in the neighborhood. As you can see, modern investors are in favor of segregating the housing and service functions. They focus primarily on the profitability of their investments. Enclosing housing estates also allows you to enrich the infrastructure with such elements as: playgrounds, walking paths, fountains, tennis courts, spas and even swimming pools. Therefore, it is very important to know the preferences of the inhabitants of the future housing estate. For this purpose, an analysis of the competition is carried out (i.e. what is being built around the investment area, what flats are checked), interviews, surveys are made, and if the company has been operating on the market for a long time, it draws on the experience of previous construction sites. An important element is also participation in development fairs, which inform about trends on the real estate market ${ }^{22}$. 


\section{SWOT analysis for the conditions of multi-family housing in Katowice}

On the basis of the conducted research, the following SWOT analysis can be constructed, Table 2 .

Table 2. SWOT analysis for conditions of multi-family housing in Katowice

\section{SWOT analysis for conditions of multi-family housing in Katowice}

S-strength

- Notations in the City Development Strategy "Katowice 2030"

- Notations in the Study of Conditions and directions of development spatial

- Housing investments of SM, especially KSM

- Development investments

- Good condition of the city in terms of economy

- Perfect location

- A large number of graduates of technical and science faculties

O - opportunities

- Establishment of the Metropolis GZM

- Improving air quality

- New municipal investments improving the image of the city

- Depopulation
W - weaknesses

- Depopulation

- An aging population

- Air condition
T - threats

- Low evaluation of Katowice's image in the general public

- No influx of new residents

Source: Own study

\section{Conclusion}

The analyzes carried out indicated the following conditions for multi-family housing in Katowice: strategic provisions in city documents, defining the direction of investment, demographic problems, i.e. primarily depopulation and aging of Katowice's society, problem with the city's image in the context of the settlement of new residents and thus the problem with the increase in demand for new apartments. In the presented SWOT analysis, the issue of depopulation appeared both as a weakness and an opportunity (chances). Weakness, because the depopulation of the city, especially its downtown, may lead to an even greater deterioration of its image and the collapse of local properties, an opportunity, as a smaller population may soon become a saturation of the housing market. However, this problem requires further research. At the same time, both cooperative and development investments are being carried out in the city, both types well thought-out, but in different aspects: KSM - in the context of a long-term construction strategy, conditioned by the economic situation of the cooperative, the city and the region, the developer - in the context of quick profit and sale of apartments, also to clients from large-block housing estates as part of internal urban migration.

The most important factor for the situation of multi-family housing will be the well-thought-out implementation of city strategies, resulting from planning documents. 


\section{References}

[1] Air pollution in Katowice: https://aqicn.org/map/katowice/pl/.

[2] City Development Strategy „Katowice 2030” https://bip.katowice.eu, accessed: 19.11.2020.

[3] Focus interview with a developer at Activ Investment, 10.11.2011.

[4] Katowice. Study of the conditions and directions of spatial development, https://bip.katowice.eu, accessed: 23.11.2020.

[5] Komar B., Interview with the developer J.W. Construction Holding SA, 18.11.2020.

[6] Komar B., The contemporary quality of the cooperative housing estate in the light of the principles of sustainable development on selected examples, Publishing House of the Silesian University of Technology, Gliwice 2014.

[7] KSM, Directions for the development of economic, social and cultural activities of the Katowice Housing Cooperative for 2020.

[8] Nykiel M., Developers do not want to build in Katowice. Why?, Gazeta Wyborcza, 27.07.2016.

[9] Regulation of the Council of Ministers of June 26, 2017 on the establishment of a metropolitan union in the Silesian Voivodeship under the name Metropolis GZM (Journal of Laws of 2017, item 1290).

[10] Report on metropolises: Katowice. The Silesian diamond needs a better cut, PwC, 2015, https://www.pwc.pl/pl/pdf/ miasta/raport-o-metropoliach-katowice-2015.pdf, accessed on: 24, 25.11.2020.

[11] Resolution No. LII / 1068/05 of the Katowice City Council of December 19, 2005. on the development Strategy of the City of Katowice.

[12] Runge J., Socio-economic and spatial manifestations of suburbanization in the Silesian Voivodeship [in]: Słodczyk J. (ed.) Processes of suburbanization in selected Polish cities, Urban Studies volume 3, Publishing House of the University of Opole, Opole 2011.

[13] Runge J., Tendencies of depopulation and demographic aging in the Ślaskie Voivodeship and the model of the new re-urbanization of the region [in]: Gasidło K., Klasik A., Muster R., New urbanization on the old substrate, Publishing House of the University of Economics, Katowice 2019, p. 102-112. 